Index to Statements, Guidelines and Policy Docu ments of the College (1971-1989), with annual supplements. OP 6. £2.50.

List of Books Suitable for a Psychiatric Library (1994) OP 26. £2.00.

Reading List for Trainees: Basic Sciences (1993) OP 21. £2.00.

Reading List for Trainees: General Psychiatry (1995) OP 28. £2.50.

Psychiatric Associations of the World (1995), OP 29. $\$ 5.00$.

\section{Library stafi}

Elizabeth M Nokes, MA ALA

Margaret Harcourt Williams (Archivist)

Josephine Kavanagh

Honorary Librarian: Dr Ian Pullen.

\section{Notice}

At the Library Committee's meeting in June, the future development of the Library and Information service was discussed, and we would now like to seek Members' views on how the service should develop.

What services do Members want the Library to supply? What materials should it be collecting? What areas of information technology should it develop?

If you have comments or suggestions to make, on the future development of the Library, the Library committee would welcome them.

Please make your comments in writing to the Temporary Librarian, Miss Elizabeth M. Nokes, via the College.

\section{Recent donations}

We wish to thank the following author-Members and others, who have generously donated copies of their works to the College Library.

The last such acknowledgement appeared in the January 1995 issue of the Psychiatric Bulletin: there has therefore been a long gap. We apologise if any Member has been overlooked, and, if notified of it, will do our best to rectify the omission.

British Council. Guide to Postgraduate Degrees, Diplomas and Courses in Medicine 1996

British Medical Association, Assessment of Mental Capacity, Guidance for Doctors and Lawyers

Kevin Brown. The Leavesden Hospital Story, 1870-1995

Dr J. Catalan, Psychological Medicine of HIV Infection

Dr David H. Clark, Descent into Conflict, 1945. A Doctor's War

Dr Christopher Cordess \& Dr Murray Cox, Forensic Psychotherapy

Dr J. H. Downson, Personality Disorders Recognition and Clinical Management

Dr S. Fernando, Mental Health in a multi-ethnic Society. A Multi-Disciplinary Handbook

Dr M. Fitzgerald, Irish Families Under Stress, Vol. 4
Dr M. Gopfert, Parental Psychiatric Disorder

Dr L. Holmes, Introduction to Psychoanalysis, contemporary Theory and Practice

Dr Tony Maden, Women, Prisons and Psychiatry: Mental Disorder Behind Bars

Dr Peter J McKenna, Purchasing Care for Patients with Schizophrenia

Professor E. Murphy, Geriatric Psychiatry: Key Research Topics for Clinicians

Professor D. J. Nutt, Benzodiazepine Receptor Inverse Agonists

Professor D. J. Nutt, Clinical Psychiatry, Hypnotics and Anviolytics

Eric H. Pryor, A Pictorial Review of Claybury Hospital

Dr Peter Reder, Assessment of Parenting, Psychiatric and Psychological Contributions

Dr Mary Robertson, Psychiatry at a Glance

Dr A. Ryle, Cognitive Analytic Therapy, Developments in Theory and Practice

Professor Tsiantis, The Children of the Leros Asylum

Dr Michael Trimble, Biological Psychiatry 2nd edn Dr Sula Wolff, Loners: The Life Path of Unusual Children

Adina Wrobleskd, Suicide: Survivors. A Guide for those Left Behind

Adina Wrobleskd, Suicide: Why? 85 Questions and Answers About Suicide

We also wish to thank Dr Connell, who gave a collection of a number of items to the College Library, in the spring of 1995.

This list is an acknowledgement of donors, not a current awareness or latest acquisitions list. If members are interested in the publications listed, they are welcome to contact the Library, which can supply full bibliographic detalls from the database. 